\title{
PENGARUH KOMPETENSI KEUANGAN TERHADAP LITERASI KEUANGAN BAGI WANITA DI MAKASSAR
}

\author{
${ }^{1}$ Budi Rustandi Kartawinata, ${ }^{2}$ Muhammad Ikhwan Mubaraq \\ 1,2 Universitas Telkom \\ Emai: budi.kartawinata@gmail.com
}

\begin{abstract}
Currently women hold a vital role both in business even in household. Given that the group has a very strategic position because this group becomes a determinant in decision making of household financial. Therefore, the financial literacy of women is very needed to be a guide in the financial decision making process so that the role of women can run properly and appropriately. This research aims to determine the influence of financial behavior, financial attitude, and financial knowledge on financial literacy of well educated women in Makassar city. This research is a quantitative research with descriptive and causal data analysis. Respondents studied in this research numbered to 100 well-educated women in Makassar. This study uses four variables, namely three independent variables and one dependent variable. The independent variable consists of financial behavior, financial attitude, and financial knowledge while the dependent variable is financial literacy. The results of this study indicate that the financial behavior is in the position of $73.74 \%$ and included in good category. Financial attitude has a percentage of $82.47 \%$ and included in good category. Financial knowledge has a percentage of $84.57 \%$ and included in excellent category. Financial literacy has a percentage of $78.52 \%$ and included in good category. The results of this research indicate that financial knowledge has a significant influence on financial literacy.
\end{abstract}

Key Words : Financial Literacy, Financial Behaviour, Financial Attitude, Financial Knowledge, Women

\begin{abstract}
ABSTRAK
Saat ini wanita memegang peranan vital baik dalam bisnis maupun rumah tangga. Hal ini mengingat golongan tersebut memiliki posisi yang sangat strategis karena golongan ini menjadi penentu dalam pengambilan keputusan keuangan rumah tangga. Maka dari itu literasi keuangan yang dimiliki wanita sangat diperlukan untuk menjadi pedoman dalam proses pengambilan keputusan keuangan agar peran wanita tersebut dapat berjalan dengan baik dan tepat. Penelitian ini bertujuan untuk mengetahui pengaruh financial behaviour, financial attitude, dan financial knowledge terhadap financial literacy pada wanita berpendidikan tinggi di Kota Makassar. Penelitian ini merupakan penelitian kuantitatif dengan analisis data deskriptif dan kausal. Responden yang diteliti dalam penelitian ini berjumlah 100 orang wanita berpendidikan tinggi di Kota Makassar. Penelitian ini menggunakan empat variabel yaitu tiga variabel bebas dan satu variabel terikat. Variabel bebas terdiri dari variabel financial behaviour, financial attitude, dan financial knowledge sedangkan variabel terikat yaitu variabel financial literacy. Hasil penelitian ini menunjukkan bahwa financial behaviour berada pada posisi angka 73,74\% dan termasuk dalam kategori baik. Financial attitude memiliki persentase sebesar $82,47 \%$ dan termasuk dalam kategori baik. Financial knowledge memiliki persentase sebesar 84,57 dan termasuk dalam kategori sangat baik. Financial literacy memiliki persentase sebesar 78,52\% dan termasuk dalam kategori baik. Hasil penelitian ini menunjukkan bahwa financial knowledge memiliki pengaruh signifikan terhadap financial literacy.
\end{abstract}

Kata Kunci : Financial Literacy, Financial Behaviour, Financial Attitude, Financial Knowledge, Wanita 


\section{PENDAHULUAN}

Pemeritah sedang menggalakkan literasi keuangan saat ini, hal ini disebabkan saat ini era disrupsi yang ada, dimana dalam sektor keuangan setiap individu memiliki kontrol uang tinggi dalam pengelolaan keuangannya. Seseorang dengan literasi keuangan yang baik (well literate), akan mampu melihat uang dengan sudut pandang yang berbeda dan memiliki kendali atas kondisi keuangannya. Orang tersebut akan memahami bagaimana mereka mengelola pendapatan dan pengeluarannya untuk menjamin kelangsungan hidupnya dimasa yang akan datang. Lusardi \& Mithcell (2014) berargumen bahwa literasi keuangan penting untuk menghasilkan keputusan keuangan yang tepat, dimana individu-individu yang mempunyai pengetahuan yang kurang lebih banyak mengalami berbagai macam kesalahan dalam keputusan keuangan mereka.

\section{Tabel 1}

Indeks Literasi Keuangan Beberapa Negara Asia Tenggara Tahun 2013

\begin{tabular}{|l|l|c|} 
NO & \multicolumn{1}{|c|}{ Negara } & $\begin{array}{c}\text { Indeks Literasi Keuangan } \\
\mathbf{2 0 1 3}\end{array}$ \\
\hline 1 & Singapura & $98 \%$ \\
\hline 2 & Thailand & $73 \%$ \\
\hline 3 & Malaysa & $66 \%$ \\
\hline 4 & Filipina & $27 \%$ \\
\hline 5 & Indonesia & $21,84 \%$ \\
\hline
\end{tabular}

Sumber : Otoritas Jasa Keuangan

Dilihat dari data yang diberikan oleh Otoritas Jasa Keuangan (OJK) pada tahun 2013, posisi indeks literasi keuangan Indonesia ada di peringkat ke lima di regional asia tenggara (ASEAN), di bawah Singapura, Thailand, Malaysia, dan Filipina. Hal ini menggambarkan bahwa Warga Negara Indonesia memiliki tingkat literasi yang rendah sehingga setiap individu memili pengelolaan keuangan yang rendah. Padahal dengan tingkat Iterasi yang rendah menyebabkan Rendahnya financial literacy akan menyebabkan kesalahan dalam pengambilan keputusan keuangan dan dapat berdampak negatif dalam pengelolaan keuangan masyarakat di masa yang akan datang.

Tabel 2

Indeks Literasi Keuangan Dan Inklusi Keuangan Berdasarkan Gender

\begin{tabular}{|l|l|l|l|l|}
\hline \multirow{2}{*}{ NO } & \multicolumn{2}{|l|}{ Indeks Literasi Keuangan } & \multicolumn{2}{|l|}{ Indeks Inklusi Keuangan } \\
\cline { 2 - 5 } & Pria & Wanita & Pria & Wanita \\
\hline 1 & $33 \%$ & $25 \%$ & $69 \%$ & $60 \%$ \\
\hline
\end{tabular}

Sumber: Otoritas Jasa Keuangan

Dari data di atas, digambarkan saat ini literasi keuangan berdasarkan gender di Indonesia, dimana untuk kaum wanita sebesar $33 \%$ dan kaum pria sebesar $33 \%$. Hal ini berarti bahwa tingkat literasi keuangan wanita jaug lebih rendah dibandingkan pria. Hal ini cukup cukup mengkhawatirkan karena seperti yang kita keyahui, bahwa dalam kegiatan sehari-hari untuk pengelolaan keuangan, wanita memegang kontrol yang tinggi dibandingkan dengan pria, contoh dalam sebuah keluarga, ada ungkapan bahwa yang menjadi direktur keuangan dalam keluarga itu adalah Ibu atau Istri. Hal ini akan menjadi masalah ketika direktur keuangannyanya memiliki literasi keuangan yang rendah, maka dapat dipastikan akan mengganggu berjalannya pengelolaan di dalam keluarga. Pemahaman (literasi) finansial wanita di Indonesia lebih rendah dibandingkan laki-laki. Oleh karena itu Otoritas Jasa Keuangan (OJK) berusaha untuk meningkatkan literasi keuangan wanita. 
Wanita memegang peranan vital baik dalam bisnis maupun rumah tangga saat ini.. Otoritas Jasa Keuangan (OJK) pada tahun 2015 merilis survei yang mereka lakukan terhadap wanita. Hasilnya wanita memegang peranan besar dalam pengambilan keputusan di keuangan bisnis dan keluarga. Mereka bertanggung jawab atas $51 \%$ perencanaan keuangan keluarga dan 33\% usaha kecil di Indonesia. Tidak hanya itu, 57\% pengguna produk dan layanan keuangan adalah wanita. Melihat peran yang begitu besar dari perempuan maka diperlukan pengetahuan dan pemahaman mengenai konsep keuangan agar dapat terhindar dari kesalahan dalam pengambilan keputusan keuangan (nasional.sindonews.com diakses pada tanggal 5 September 2017).

Organization For Economic Co-Operation and Development (OECD) mendefinisikan bahwa untuk mengukur literasi keuangan adalah kombinasi dari kesadaran , pengetahuan, kemampuan, sikap, dan perilaku yang diperlukan untuk membuat keputusan keuangan (Atkinson dan Messy, 2012). Sehingga OECD menggambarkan literasi keuangan ke dalam tiga faktor yaitu financial attitude, financial behaviour dan financial knowledge. Menurut Potrich (2015) dalam mengukur financial literacy yang dilakukan dengan menggunakan tiga faktor, meliputi financial attitude, financial behaviour dan financial knowledge. Dari ketiga aspek inilah maka dapat diterapkan menjadi tingkat kompetensi keuangan.

Sulawesi Selatan merupakan salah satu provinsi di Kawasan Timur Indonesia (KTI) yang memiliki pertumbuhan ekonomi diatas rata-rata Nasional yaitu sebesar $8,05 \%$ pada tahun 2016. Perputaran ekonomi, investasi dan keuangan provinsi Sulawesi Selatan berpusat pada ibu kota provinsi yaitu Kota Makassar. Pertumbuhan ekonomi Kota Makassar juga berada di atas rata-rata nasional yaitu sebesar 7,9\% pada tahun 2016 . Hal ini menunjukkan Kota Makassar memiliki peran penting dalam pertumbuhan ekonomi di Sulawesi Selatan dan dapat dijadikan contoh bagi kota-kota besar lainnya di Indonesia. Pertumbuhan ekonomi Kota Makassar harus disertai dengan pengetahuan literasi keuangan yang baik agar masyarakat dapat mengelola keuangannya dengan baik sehingga pertumbuhan ekonomi yang baik di Kota Makassar tersebut dapat sustain atau berkelanjutan. Namun berdasarkan data otoritas, hanya sekitar 200.000 orang yang melek keuangan atau 14,2\% dari total penduduk Makassar yang mencapai 1,4 juta orang. Ini juga jauh berbeda dengan indeks literasi keuangan Provinsi Sulawesi Selatan yaitu sebesar $28,36 \%$. (www.finansial.bisnis.com diakses pada tanggal 5 September 2017).

Ketika literasi keuangan baik, maka seharusnya keputusan dalam pengelolaan keuangan juga harusnya tepat. Namun, berdasarkan data diatas pinjaman yang disalurkan oleh perbankan di Kota pinjaman konsumsi merupakan alokasi terbesar. Pinjaman konsumsi yang disalurkan menunjukkan peningkatan dari tahun 2013 sebesar 20.937.342 juta menjadi 21.981.879 juta di tahun 2014. Berdasarkan data tersebut menunjukkan bahwa keputusan keuangan di Kota Makassar cenderung rendah dikarenakan mereka menggunakan pinjaman perbankan untuk hal-hal yang kurang produktif. Hal tersebut menjadi fenomena yang menunjukkan adanya literasi keuangan yang kurang baik di Kota Makassar.

Berdasarkan fenomena dan permasalahan yang telah dijelaskan diatas, penulis bermaksud melakukan penelitian yang berjudul "PENGARUH KOMPETENSI KEUANGAN TERHADAP LITERASI KEUANGAN BAGI WANITA DI KOTA MAKASSAR"

\section{LANDASAN TEORI}

\section{Financial Behaviour}

Menurut Mydhili Virigineni dan M. Bhaskara Rao (2017) Behavioral finance adalah studi tentang psikologi manusia dan rasionalitas dalam membuat keputusan keuangan dikurangi asumsi tradisional tentang maksimalisasi utilitas yang diharapkan di pasar yang efisien.

Behavioral Finance adalah suatu disiplin ilmu yang didalamnya terdapat interaksi dari berbagai disiplin ilmu dan secara terus meneruts berintegrasi sehigga 
pembahasaannya tidak dilakukan isolasi, (Ricciadi, 2000). Ada 3 aspek yang mempengaruhi behavioral finance, yaitu:

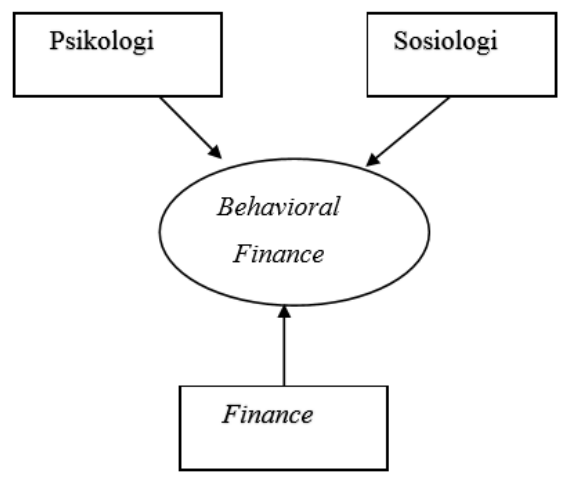

\section{Gambar 1 \\ Behavioral Finance \\ Sumber : Ricciadi, 2000}

Menurut gambar 2.1 mengenai dimensi behavioral finance, terdapat tiga aspek yang mempengaruhi perilaku keuangan yakni psikologi, sosiologi, dan keuangan. Seseorang yang ingin mempelajari dan memahami perilaku keuangan harus memiliki pengertian mengenai aspek psikologi, sosiologi, dan keuangan. Tiga aspek ini akan memperkuat behavioral finance seseorang.

Behavioral finance dapat didefinisikan sebagai elemen penting dari literasi keuangan, sedangkan studi terbaru terkait behavioral finance sebagai elemen literasi keuangan, (Lusardi dan Mitchell, 2013).

Sewell dalam Hemanathan (2011) berpendapat bahwa behavioral finance adalah ilmu atau studi mengenai pengaruh psikologi terhadap tindakan praktisi keuangan dan dampaknya terhadap pasar di masa yang akan datang.

Menurut Heck dalam Agatha (2017) terdapat sembilan daftar personal financial management behaviour yang baik, dimana empat poin pertama sebagai "perilaku perencanaan" dan lima poin sebagai "penerapan perilaku", meliputi:

1. Menerapkan tujuan keuangan.

2. Memperkirakan biaya secara akurat.

3. Memperkirakan pendapatan secara akurat.

4. Perencanaan belanja dan penganggaran.

5. Mempertimbangkan beberapa alternatif ketika membuat keputusan keuangan.

6. Menyesuaikan untuk memenuhi keadaan darurat keuangan.

7. Membayar tagihan tepat waktu.

8. Berhasil memenuhi tujuan keuangan.

9. Berhasil melaksanakan rencana belanja.

\section{Financial Attitude}

Menurut Robbins \& Judge (2008), sikap dapat diartikan sebagai pernyataan yang evaluatif baik yang menyenangkan maupun yang tidak menyenangkan terhadap objek, individu, dan peristiwa. Sikap memiliki 3 komponen utama yang terdiri dari :

1. Kognitif adalah opini atau keyakinan dari suatu sikap yang menentukan tingkatan untuk sesuatu atau bagian yang lebih penting dari sikap.

2. Afektif (perasaan) adalah suatu emosional yang berada dalam diri setiap individu. Perasaan merupakan suatu pernyataan dari sikap yang diambil dan ikut menentukan perilaku yang akan dilakukan oleh setiap individu.

3. Perilaku atau tindakan merupakan cerminan dari bagaimana individu berperilaku dalam cara tertentu terhadap sesuatu atau seseorang. 
Financial Attitude yang dimiliki oleh seseorang akan membantu individu tersebut dalam hal pengelolaan keuangan, penganggaran keuangan pribadi dan bagaimana keputusan individu mengenai bentuk investasi yang akan diambil, (Robbin dan Judge, 2008).

Parrotta dan Johnson dalam Mien dan Thao (2015) mengemukakan bahwa financial attitude dapat dianggap sebagai kecenderungan psikologis yang diungkapkan ketika mengevaluasi praktik manajemen keuangan dengan beberapa tingkatan persetujuan atau ketidaksetujuan.

Gina A.N. Chowa, Mat Despard, \& Isaac Osei-Akoto (2012) menjelaskan bahwa sikap keuangan mengacu kepada keyakinan dan nilai seseorang yang terkait dengan berbagai konsep keuangan pribadi, seperti percaya bahwa pentingnya untuk menghemat uang.

Menurut Furnham dalam Mien dan Thao (2015) menyatakan bahwa financial attitude membentuk cara orang dalam menghabiskan, menyimpan, menimbun dan membuang uang. Sejumlah penelitian telah menyimpulkan bahwa financial attitude berperan penting dalam menentukan perilaku keuangan seseorang, (Davis dan Schum dalam Mien dan Thao, 2015).

Moore dalam J.B.R (2014) financial attitude merupakan faktor yang mendorong keadaan pikiran individu dalam membuat keputusan selama transaksi. Attitude yang dikombinasikan dengan financial knowledge dan behavioral finance dapat bersinergi dalam mendorong hasil dari sebuah keputusan keuangan yang akan diambil.

Pankow (2012) menyatakan bahwa Financial attitude adalah ukuran keadaan pikiran, pendapatan dan penilaian seseorang terhadap dunia yang ditinggali. Sehingga financial attitude dapat diartikan sebagai keadaan pikiran, pendapat dan penilaian seseorang terhadap keuangan pribadinya yang diaplikasikan ke dalam sikap.

\section{Financial Knowledge}

Knowledge atau pengetahuan dapat diartikan sebagai fakta atau kondisi mengetahui sesuatu dari pengalaman. Pengetahuan keuangan adalah sebuah dimensi integral, tetapi tidak sama dengan literasi keuangan. Literasi keuangan mengharuskan seseorang memiliki kemampuan dan kepercayaan diri untuk menggunakan pengetahuan keuangannya untuk membuat keputusan keuangan. Menurut Houston (2010) menjelaskan ketika menentukan instrumen untuk menentukan literasi keuangan, penting untuk menentukan bahwa orang tersebut tidak hanya mengetahui informai keuangan tetapi juga dapat menerapkannya dengan tepat,

Delavande et al (2008) pengetahuan keuangan adalah jenis tertentu dari modal yang diperoleh dalam kehidupan melalui pembelajaran kemampuan untuk mengelola pendapatan, pengeluaran dan tabungan dengan cara yang aman. Garman dan Forgue dalam Mien dan Thao, (2015) menyatakan financial knowledge didefinisikan sebagai pengetahuan yang cukup mengenai fakta-fakta keuangan pribadi dan merupakan kunci untuk perilaku pengelolaan keuangan pribadi

Financial knowledge secara teoritis berarti pengetahuan tentang bagaimana pasar keuangan beroperasi harus menghasilkan individu yang membuat pinjaman lebih efektif keputusan, (Liebermann \& Flint-Goor, 1996).

Pengetahuan keuangan saja tidak cukup untuk manajemen keuangan yang efektif, sebagai pengaruh pengetahuan keuangan pada perilaku diukur melalui sikap keuangan, (Norvilitis dan Maclean, 2010)

Parker et al. Dalam Assad (2015) menunjukkan bahwa dua dimensi dari pengetahuan keuangan, subjektif, dan objektif memainkan peran yang berbeda dalam mempengaruhi perilaku seseorang. Artinya, dua individu dengan pengetahuan keuangan yang sama bisa memiliki evaluasi subjektif yang berbeda, yang menyebabkan hasil perilaku yang berbeda. 


\section{Concept of literacy}

Literasi menurut Department for International Development (UK); United States Agency for International Development; World Bank berhubungan dengan kemampuan dasar (membaca, menulis dan menghitung) atau kompetensi. Definisi literasi adalah satu dari kemampuan pengetahuan dasar yang dapat dibuktikan (Canadian International Development Agency; Danish International Development Assistance; New Zealand's International Aid and Development Agency). Remund (2010) menjelaskan bahwa konsep literasi pada dasarnya berhubungan dengan kumpulan pengetahuan dan keterampilan yang diperlukan untuk memenuhi tuntutan hidup dalam masyarakat yang demokratis. Dengan demikian, literasi terdapat dalam berbagai bidang seperti bidang politik, lingkungan, budaya dan keuangan.

\section{Financial Literacy}

Menurut Otoritas Jasa Keuangan (OJK) literasi keuangan dapat diartikan sebagai rangkaian proses atau aktivitas untuk meningkatkan pengetahuan (knowledge), keterampilan (skill) dan keyakinan (confidence) konsumen dan masyarakat luas sehingga mereka mampu mengelola keuangan pribadi lebih baik.

Clercq \& Venter (2009) menjelaskan bahwa financial literacy adalah sebagai kemampuan untuk membaca, menganalisis, mengelola dan mengkomunikasikan tentang kondisi keuangan yang dapat mempengaruhi secara positif terhadap kesejahteraan material. Schagen and Lines (1996) menyatakan financial literacy mengacu pada kemampuan seseorang untuk memahami dan menggunakan konsep keuangan. Hal ini selaras dengan Penilitian Roy Morgan (2003a, 2003b, 2003c) juga menjelaskan bahwa literasi keuangan adalah orang-orang yang diberi tahu dan percaya diri dalam semua aspek penganggaran, pengeluaran, dan penghematan mereka, tetapi tingkat literasi keuangan itu tercermin secara individu sehingga bersifat relatif.

Hogarth (2002) menemukan bahwa literasi keuangan mencakup pengetahuan dan pemahaman tentang konsep keuangan dasar dan kemampuan untuk menggunakannya dalam merencanakan dan menerapkan keputusan keuangan.

Menurut Chen dan Volpe (1998) menyatakan literasi keuangan adalah pengetahuan untuk melaksanakan keuangan dalam pengambilan keputusan keuangan. Hal ini mencakup bagaiana seseorang atau mengalokasikan keuangannya bukan hanya untuk kebutuhan saat ini juga namun untuk kebutuhan masa depan. Garman dan Forgue (2010:4) menyebutkan literasi keuangan adalah pengetahuan tentang fakta, konsep, prinsip dan alat teknologi yang mendasari untuk dapat cerdas dalam menggunakan uang.

Robert T. Kiyosaki (2008) menjelaskan financial literacy sebagai kemampuan untuk membaca dan memahami halhal yang berhubungan dengan masalah finansial/keuangan. Financial literacy menurut Huston (2010:307-308) diartikan sebagai komponen sumber daya manusia yang dapat digunakan untuk meningkatkan kesejahteraan keuangan, seseorang dikatakan melek keuangan ketika memiliki pengetahuan dan kemampuan untuk menerapkan pengetahuan tersebut. (Kim et al., 2001) literasi keuangan adalah kemampuan untuk memahami konsep keuangan utama yang diperlukan untuk berfungsi dalam masyarakat Amerika yang normal.

Dengan kata lain financial literacy pribadi merupakan kemampuan untuk membaca, menganalisis, mengelola, dan berkomunikasi tentang kondisi keuangan pribadi yang mempengaruhi kesejahteraan ekonomi. Hal ini mencakup kemampuan untuk membedakan pilihan keuangan, mendiskusikan masalah keuangan, rencana masa depan, dan kompetensi menanggapi peristiwa kehidupan yang mempengaruhi keputusan keuangan sehari-hari maupun peristiwa dalam perekonomian secara umum

Houston (2010) menjelaskan bahwa literasi keuangan memiliki dua dimensi yaitu: pemahaman yang merupakan pengetahuan keuangan pribadi serta pendidikan keuangan dan penggunaan yang berarti penerapan manajemen pengetahuan keuangan pribadi. 
Menurut Remund (2010) literasi keuangan merupakan kemampuan seseorang untuk memahami dan menggunakan masalah keuangan. Dalam penelitian ini, untuk mengukur tingkat literasi keuangan pribadi menggunakan lima domain menurut Remund. Remund (2010) menyebutkan terdapat lima domain dari literasi keuangan yaitu;

1. Pengetahuan tentang konsep keuangan,

2. Kemampuan untuk berkomunikasi tentang konsep keuangan,

3. Kemampuan untuk mengelola keuangan pribadi,

4. Kemampuan dalam membuat keputusan keuangan,

5. Keyakinan untuk membuat perencanaan keuangan dimasa depan

\section{METODOLOGI}

Penelitian ini menggunakan metode kuantitatif. Menurut Sugiyono (2015:13) metode kuantitatif adalah metode penelitian yang meneliti pola populasi atau sampel tertentudan berlandaskan pada paham positivisme. Pengumpulan data dari metode ini menggunakan instrumen penelitian dan analisis data bersifat kuantitatif atau statistik dengan tujuan untuk menguji hipotesis yang telah diterapkan. Metode ini disebut metode kuantitatif karena data penelitian berupa angka-angka dan analisis menggunakan statistik.

Tujuan penelitian ini adalah deskriptif. Penelitian deskriptif merupakan penelitian yang menggambarkan karakteristik dari objek, orang, kelompok, organisasi, ataupun lingkungan (Zikmund dan Babin, 2013:49). Berdasarkan dari tipe penyelidikan penelitian ini (types of investigation) merupakan penelitian kausal merupakan penelitian yang menerangkan hubungan sebab akibat antara variabel independen (variabel yang mempengaruhi) dan variabel dependen (variabel yang dipengaruhi) (Sugiyono, 2013:56).

Penelitian dapat dibedakan berdasarkan tingkat keterlibatan peneliti dalam melakukan manipulasi data sesuai tujuan penelitiannya. Tingkat keterlibatan peneliti dibagi menjadi dua yakni mengintervensi dan tidak mengintervensi data, Indrawati (2015:117). Dimana penelitian ini berdasarkan tingkat keterlibatan peneliti menggunakan tidak mengintervensi data atau peneliti tidak melakukan manipulasi data.

Waktu pelaksanaan (time horizon) dari penelitian ini menggunakan cross sectional. Menurut Indrawati (2015:118), cross sectional yaitu waktu pelaksanaan pengumpulan data dilakukan dalam satu periode, kemudian data itu diolah, dianalisis, dan kemudian ditarik kesimpulannya.

Menurut Sugiyono (2014:167) skala pengukuran merupakan kesepakatan yang digunakan sebagai acuan untuk menentukan panjang pendeknya interval yang ada dalam alat ukur, sehingga alat ukur tersebut bila digunakan dalam pengukuran akan menghasilkan data kuantitatif. Variabel-variabel tersebut diukur oleh instrumen pengukur dalam bentuk kuesioner berskala ordinal yang memenuhi pernyataan-pernyataan tipe skala likert. Didalam Sugiyono (2014:168) skala likert digunakan untuk mengukur sikap, pendapat, dan persepsi seseorang atau sekelompok orang tentang fenomena sosial. Skala Likert menggunakan skala lima pilihan yaitu : Sangat tidak setuju, tidak setuju, netral, setuju, dann sangat setuju (strongly disagree, disagree, neither agree nor disagree, agree, and strongly agree). Berikut adalah Tabel tentang susunan dan pemberian skor pada skala Likert.

Menurut Indrawati (2015:124) operasionalisasi variabel adalah suatu proses menurunkan variabel-variabel yang terkandung di dalam masalah penelitian menjadi bagian-bagian terkecil sehingga dapat diketahui klasifikasi ukurannya, sehingga mempermudah mendapatkan data diperlukan bagi penilaian masalah penelitian.

Dalam hal ini variabel adalah adanya atribut dari suatu kelompok yang berbeda yang memiliki nilai variasi antara satu dan lainnya, sehingga didapatkan informasi dan dapat ditarik kesimpulannya. Variabel yang penulis gunakan adalah financial behaviour, financial attitude, , financial knowledge, dan financial literacy. 
Tabel 3

Operasionalisasi Variabel

\begin{tabular}{|c|c|c|c|c|}
\hline No & Variabel & Definisi & Indikator & $\begin{array}{l}\text { Skala/ } \\
\text { Ukuran }\end{array}$ \\
\hline & $\begin{array}{l}\text { Financial } \\
\text { Behaviour } \\
\text { (Ricciardi } \\
2000 \text { ) } \\
\text { Variabel } \\
\text { X1 }\end{array}$ & $\begin{array}{l}\text { Ada tiga aspek yang } \\
\text { mempengaruhi perilaku } \\
\text { keuangan adalah psikologi, } \\
\text { sosiologi dan keuagan. }\end{array}$ & $\begin{array}{l}\text { 1. Psikologi } \\
\text { 2. Sosiologi } \\
\text { 3. Keuangan }\end{array}$ & Ordinal - likert \\
\hline & $\begin{array}{l}\text { Financial } \\
\text { Attitude } \\
\text { (Robbins \& } \\
\text { Judge } \\
2008 \text { ) } \\
\text { Variabel } \\
\text { X2 }\end{array}$ & $\begin{array}{l}\text { Financial Attitude yang } \\
\text { dimiliki oleh seseorang } \\
\text { membantu individu tersebut } \\
\text { dalam hal pengelolaan } \\
\text { keuangan, penganggaran } \\
\text { keuangan pribadi dan } \\
\text { bagaimana keputusan } \\
\text { individu mengenai bentuk } \\
\text { investasi yang akan diambil. }\end{array}$ & $\begin{array}{l}\text { 1. Pengelolaan } \\
\text { keuangan } \\
\text { 2. Penganggaran } \\
\text { keuangan } \\
\text { 3. Keputusan } \\
\text { individu } \\
\text { mengenai } \\
\text { bentuk yang } \\
\text { akan diambil }\end{array}$ & Ordinal - likert \\
\hline & $\begin{array}{l}\text { Financial } \\
\text { Knowledge } \\
\text { (Houston } \\
2010) \\
\text { Variabel } \\
\text { X3 }\end{array}$ & 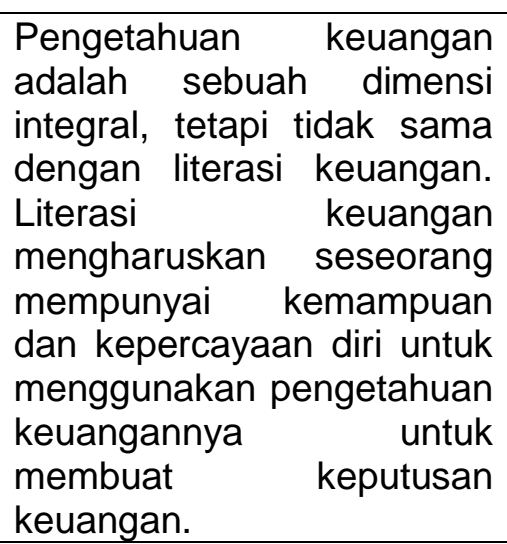 & $\begin{array}{l}\text { 1. Basic financal } \\
\text { Knowleddge } \\
\text { 2. Advanced } \\
\text { financial } \\
\text { knowledge }\end{array}$ & Ordinal - likert \\
\hline & $\begin{array}{l}\text { Financial } \\
\text { Literacy } \\
\text { (Houston } \\
2010) \\
\text { Variabel Y }\end{array}$ & $\begin{array}{l}\text { Literasi keuangan memiliki } \\
\text { dua dimensi: pemahaman } \\
\text { yang merupakan } \\
\text { pengetahuan keuangan } \\
\text { pribadi serta pendidikan } \\
\text { keuangan dan penggunaan } \\
\text { yang berarti penerapan } \\
\text { manajemen pengetahuan } \\
\text { keuangan pribadi }\end{array}$ & $\begin{array}{l}\text { 1. Pengetahuan } \\
\text { konsep } \\
\text { keuangan } \\
\text { 2. Kemampuan } \\
\text { berkomunikasi } \\
\text { tentang konsep } \\
\text { keuangan } \\
\text { 3. Kemampuan } \\
\text { untuk } \\
\text { mengelola } \\
\text { keuangan } \\
\text { pribadi } \\
\text { 4. Kemamuan } \\
\text { membuat } \\
\text { keputusan } \\
\text { keuangan } \\
\text { 5. Keyakinan } \\
\text { untuk membuat } \\
\text { perencanaan } \\
\text { keuangan masa } \\
\text { depan. }\end{array}$ & Ordinal - likert \\
\hline
\end{tabular}


Populasi adalah keseluruhan kelompok orang, kejadian, benda-benda yang menarik peneliti untuk ditelaah. Populasi yang dipilih peneliti untuk ditelaah akan menjadi pembatas dari hasil penelitian yang diperoleh (Indrawati, 2015:164). Populasi dalam penelitian ini adalah masyarakat Kota Makassar yang berjenis kelamin perempuan dan telah menyelesaikan pendidikan minimal Diploma III. Total populasi dalam penelitian ini adalah sebesar 82.165 orang ( Data BPS Kota Makassar Tahun 2015 yang diolah oleh peneliti).

Menurut Sugiyono (2015:136) sampel adalah bagian dari jumlah dan karakteristik yang dimiliki oleh populasi tersebut. Teknik sampling yang digunakan dalam penelitian ini adalah Probability Sampling. Menurut Indrawati (2015:166) probability sampling adalah teknik sampling yang memungkinkan anggota-anggota dalam populasi mempunyai peluang atau probabilitas yang sama untuk dipilih sebagai sampel.

Sampel adalah bagian dari jumlah dan karakteristik yang dimiliki oleh populasi tersebut yang dianggap bisa mewakili seluruh populasi (Sugiyono 2012:149). Dalam penelitian ini, sampel diambil dari data penduduk wanita berumur 15 tahun keatas berdasarkan STTB/ljazah yang ditamatkan (DIII, S1, S2 dan S3). Untuk menentukan sampel peneliti menggunakan rumus Slovin sebagai berikut:

Keterangan:

$$
n=\frac{N}{1+N e^{2}}
$$

$\mathrm{n} \quad=$ Jumlah Sampel

$\mathrm{N} \quad=$ Jumlah Populasi

$\mathrm{e} \quad=$ Persentase kelonggaran ketidaktelitian

Peneliti menggunakan persentase kelonggaran ketidaktelitian (e) sebesar 10\%. Apabila dilakukan perhitungan menggunakan rumus, maka jumlah sampel minimum yang diperoleh adalah:

$n=\frac{103.751}{1+103.751(0.1)^{2}}$

$n=99,90 \approx 100$ responden

Berdasarkan hasil hitung sampel, diperoleh angka 99 untuk jumlah sampel minimum, tetapi penulis membulatkannya menjadi 100 responden untuk mengurangi kesalahan pengisian kuesioner.

\section{HASIL DAN PEMBAHASAN}

\section{Pembahasan mengenai hasil analisis deskriptif variabel financial behaviour $\left(X_{1}\right)$, financial attitude $\left(\mathrm{X}_{2}\right)$, financial knowledge $\left(\mathrm{X}_{3}\right)$ dan financial literacy $(\mathrm{Y})$.}

1) Hasil analisis deskriptif variabel financial behaviour $\left(X_{1}\right)$ yang telah dilakukan melalui penyebaran kuesioner pada 100 orang responden yang merupakan wanita berpendidikan tinggi di Kota Makassar dapat dilihat pada tabel 4.2. Tanggapan responden terhadap 11 item pernyataan mengenai financial behaviour termasuk dalam kategori baik dengan rata-rata presentase keseluruhan dari variabel financial behaviour diperoleh skor sebesar $73,74 \%$. Oleh karena itu dapat disimpulkan bahwa financial behaviour wanita berpendidikan tinggi di Kota Makassar sudah terlihat baik. Hal ini tercermin dari perilaku mereka dalam kehidupan sehari-hari yang telah secara aktif melakukan pencatatan keuangan, mengontrol pengelaran, serta menyesuaikan pengeluaran mereka dengan rencana keuangan yang mereka buat sebelumnya. Namun hal-hal tersebut masih dilakukan secara sederhana dalam bentuk catatan-catatan kecil atau daftar belanja. Untuk item dengan persentase terkecil adalah pernyataan alokasi penghasilan untuk membayar kartu kredit dengan presentase sebesar 57,8\% termasuk dalam kategori cukup baik. Hal ini disebabkan karena wanita berpendidikan tinggi di Kota Makassar belum sepenuhnya mengenal penggunaan kartu kredit yang erat kaitannya dengan transaksi non tunai. Sebagian besar dari mereka masih menggunakan transaksi 
secara tunai dalam kehidupan sehari-hari. Oleh karena itu untuk meningkatkan financial behaviour wanita berpendidikan tinggi di Kota Makassar agar masuk ke dalam kategori sangat baik adalah dengan memberikan edukasi terkait pencatatan keuangan yang baik, manfaat kartu kredit serta pengenalan-pengenalan produk keuangan lainnya seperti saham, deposito dan obligasi.

2) Hasil analisis deskriptif variabel financial attitude $\left(X_{2}\right)$ yang telah dilakukan melalui penyebaran kuesioner kepada 100 orang wanita berpendidikan tinggi di Kota Makassar dapat dilihat pada tabel 4.3. Tanggapan responden terhadap 8 item pernyataan mengenai financial attitude termasuk dalam kategori baik dengan rata-rata persentase keseluruhan dari financial attitude sebesar $82,47 \%$. Oleh karena itu dapat disimpulan bahwa financial attitude wanita berpendidikan tinggi di Kota Makassar berada dalam kategori baik. Hal ini disebabkan karena mereka merasa penting untuk mengelola keuangan mereka dengan baik seperti menghemat sebagian dari penghasilan, melakukan investasi dan mengontrol keuangan. Mereka telah sadar bahwa untuk mencapai target-target mereka di masa yang akan datang diperlukan pengelolaan keuangan yang baik. Namun dari 8 item financial attitude, item dengan persentase terkecil adalah pernyataan penting untuk membayar tagihan pada kartu kredit dengan persentase sebesar $77,4 \%$. Hal ini disebabkan karena belum adanya dorongan yang besar untuk menggunakan kartu kredit dalam kehidupan sehari-hari. Oleh karena itu untuk meningkatkan financial attitude wanita berpendidikan tinggi di Kota Makassar agar masuk ke dalam kategori sangat baik adalah dengan memberikan pencerdasan terkait pemanfaatan kartu kredit serta pengenalan jenis jenis investasi yang dapat menjadi sumber penghasilan baru bagi mereka.

3) Hasil analisis deskriptif variabel financial knowledge $\left(X_{3}\right)$ yang telah dilakukan melalui penyebaran kuesioner kepada 100 orang wanita berpendidikan tinggi di Kota Makassar dapat dilihat pada tabel 4.4. Tanggapan responden terhadap 7 item pernyataan mengenai financial knowledge termasuk dalam kategori sangat baik dengan rata-rata persentase keseluruhan dari financial knowledge sebesar $84,57 \%$. Berdasarkan hasil analisis deskriptif tersebut, dapat disimpulkan bahwa wanita berpendidikan tinggi di Kota Makassar telah memiliki financial knowledge yang baik. Hal tersebut tercermin dari kemampuan mereka dalam menyelesaikan perhitungan sederhana terkait kekayaan mereka jika dipengaruhi oleh pajak dan inflasi, memahami bahwa setiap jenis investasi memiliki resiko yang berbeda, serta memahami fungsi pasar saham. Untuk item dengan persentase terkecil adalah pernyataan dana investasi dapat diinvestasikan ke dalam beberapa aset seperti surat berharga dan saham. Hal ini disebabkan karena adanya keterbatasan pengetahuan dan akses produk-produk investasi sehingga mereka hanya melakukan investasi dalam bentuk rumah, mobil, apartemen, perhiasan dsb. Oleh karena itu untuk meningkatkan financial knowledge wanita berpendidikan tinggi di Kota Makassar dapat dilakukan dengan mempermudah akses untuk mendapatkan layanan investasi, memberikan pemahaman terkait time value of money dan jenis-jenis investasi yang ada.

4) Hasil analisis deskriptif variabel financial literacy $(Y)$ yang telah dilakukan melalui penyebaran kuesioner kepada 100 orang wanita berpendidikan tinggi di Kota Makassar dapat dilihat pada tabel 4.5. Tanggapan responden terhadap 5 item pernyataan mengenai financial literacy termasuk dalam kategori baik dengan rata-rata persentase keseluruhan dari financial literacy sebesar 78,52\%. Berdasarkan hasil analisis deskriptif tersebut, financial literacy wanita berpendidikan tinggi di Kota Serrang termasuk dalam kategori baik. Hal ini disebabkan karena mereka telah memiliki pengetahuan terkait cara berinvestasi yang baik untuk masa depan, perilaku menyisihkan sebagian pendapatan serta memiliki perncanaan keuangan pribadi. Untuk item dengan persentase terkecil adalah pernyataan merasa tidak boros ketika pembayaran hutang bulanan sebesar $30 \%$ dari penghasilan. Hal ini disebabkan oleh motif kekhawatiran dimana mereka tidak bisa membayar tagihan utang ketika alokasi penghasilan mereka berada pada angka 30\%. Oleh karena itu hal ini dapat ditingkatkan lagi dengan memberikan pemahaman terkait 
buku kas keuangan pribadi serta memberikan pemahaman pengelolaan hutang agar digunakan untuk hal-hal yang bersifat produktif.

\section{Pengaruh Financial Behaviour $\left(X_{1}\right)$, Financial Attitude $\left(X_{2}\right)$, Financial Knowledge $\left(X_{3}\right)$ Terhadap Financial Literacy $(\mathrm{Y})$}

1) Berdasarkan hasil uji t yang dilakukan, variabel financial behaviour $\left(X_{1}\right)$, tidak berpengaruh secara signifikan terhadap financial literacy $(\mathrm{Y})$. Hasil analisis pengujian data yang dilakukan, diperoleh nilai thitung untuk variabel financial behaviour sebesar 0,138 . Dapat diketahui bahwa thitung $0,138<t_{\text {table }} 1,984984$ dengan nilai signifikansi (sig) $=0,891>0,05$. Berdasarkan hasil tersebut dapat diketahui bahwa $\mathrm{H}_{0}$ diterima dan $\mathrm{H}_{1}$ ditolak sehingga dapat disimpulkan bahwa tidak terdapat pengaruh financial behaviour secara signifikan terhadap financial literacy. Hasil penelitian ini menyatakan bahwa faktor financial behaviour bukan merupakan faktor yang berpengaruh secara signifikan terhadap financial literacy wanita berpendidikan tinggi di Kota Makassar.

2) Berdasarkan hasil uji t yang dilakukan, variabel financial attitude $\left(X_{2}\right)$, tidak berpengaruh secara signifikan terhadap financial literacy $(Y)$. Hasil analisis pengujian data yang dilakukan, diperoleh nilai thitung untuk variabel financial attitude sebesar -0,750. Dapat diketahui bahwa $t_{\text {hitung }} 0,750<t_{\text {table }} 1,984984$ dengan nilai signifikansi $(\mathrm{sig})=0,455>$ 0,05 . Berdasarkan hasil tersebut dapat diketahui bahwa $\mathrm{H}_{0}$ diterima dan $\mathrm{H}_{1}$ ditolak sehingga dapat disimpulkan bahwa tidak terdapat pengaruh financial attitude secara signifikan terhadap financial literacy. Hasil penelitian ini menyatakan bahwa faktor financial attitude bukan merupakan faktor yang berpengaruh secara signifikan terhadap financial literacy wanita berpendidikan tinggi di Kota Makassar.

3) Berdasarkan hasil uji t yang dilakukan, variabel financial knowledge $\left(\mathrm{X}_{3}\right)$, berpengaruh secara signifikan terhadap financial literacy $(Y)$. Hasil analisis pengujian data yang dilakukan, diperoleh nilai thitung untuk variabel financial knowledge sebesar 2,532. Dapat diketahui bahwa $t_{\text {hitung }} 3,532>t_{\text {table }} 1,984984$ dengan nilai signifikansi $(\mathrm{sig})=0,013<$ 0,05 . Berdasarkan hasil tersebut dapat diketahui bahwa $\mathrm{H}_{0}$ diterima dan $\mathrm{H}_{1}$ ditolak sehingga dapat disimpulkan bahwa terdapat pengaruh financial knowledge secara signifikan terhadap financial literacy. Hasil penelitian ini menyatakan bahwa faktor financial knowledge merupakan faktor yang berpengaruh secara signifikan terhadap financial literacy wanita berpendidikan tinggi di Kota Makassar.

4) Berdasarkan uji F yang dilakukan, variabel Financial Behaviour $\left(X_{1}\right)$, Financial Attitude $\left(\mathrm{X}_{2}\right)$, Financial Knowledge $\left(\mathrm{X}_{3}\right)$ secara simultan tidak berpengaruh secara positif terhadap Financial Literacy $(\mathrm{Y})$. Hasil analisis pengujian data yang dilakukan, diperoleh $F_{\text {hitung }}<F_{\text {tabel }}(2,409<2,7)$ dan tingkat signifikansinnya 0,072 $>0,05$. Hal ini menunjukkan bahwa maka $H_{0}$ diterima dan $H_{a}$ ditolak. Hasil penelitian ini menyatakan bahwa financial behaviour, financial attitude, dan financial knowledge secara simultan tidak berpengaruh positif terhadap financial literacy wanita berpendidikan tinggi di Kota Makassar.

Haryo (2017) dalam penelitiannya mengatakan bahwa financial attitude dan financial behaviour berpengaruh terhadap financial literacy sedangkan financial knowledge tidak berpengaruh terhadap financial literacy. Reisoli Bender Filho (2015) dalam penelitiannya menjelaskan bahwa terdapat pengaruh financial behaviour terhadap financial literacy. Dalam penelitian ini, financial behaviour dan financial attitude tidak memiliki pengaruh terhadap financial literacy, sedangkan financial knowledge memiliki pengaruh terhadap financial literacy.

Berdasarkan hasil koefesien determinasi $\left(R^{2}\right)$ diperoleh nilai 0,070 yang dapat diartikan bahwa variabel financial behaviour, financial attitude dan financial knowledge mempunyai pengaruh sebesar $7 \%$, sedangkan sisanya sebesar $93 \%$ dipengaruhi oleh variabel atau faktor lain yang tidak diteliti dalam penelitian ini. Rendahnya koefesien determinasi ini kemungkinan disebabkan karena adanya faktor dominan yang mempengaruh financial literacy wanita berpendidikan tinggi di Kota Makassar salah satunya adalah budaya patriarki. Budaya Patriarki menurut Alfian Rokhmansyah (2013) di 
bukunya berjudul Pengantar Gender dan Feminisme, patriarki berasal dari kata patriarkat berarti struktur yang menempatkan peran laki-laki sebagai penguasa tunggal, sentral dan segala-galanya. Laki-laki memiliki peran sebagai kontrol utama di dalam masyarakat sedangkan wanita hanya memiliki sedikit pengaruh atau bisa dikatakan tidak memiliki hak pada wilayah-wilayah umum dalam masyarakat baik secara ekonomi, sosial poltik, dan psikologi termasuk didalamnya institusi pernikahan. Oleh karena itu, dimungkinkan bahwa financial literacy wanita berpendidikan tinggi sangat dipengaruhi oleh budaya patriarki tersebut sehingga mereka memiliki keterbatasan dalam mengelola keuangan pribadi mereka, mengambil keputusan keuangan, serta meningkatkan pemahaman mereka terkait keuangan mereka. Namun seiring berjalannya waktu, budaya patriarki di Kota Makassar akan perlahan menghilang seiring masuknya budaya perkotaan yang menuntut kesetaraan gender di seluruh lapisan masyarakat Kota Makassar.

\section{PENUTUP}

Berdasarkan analisis hasil penelitian dan pembahasan yang telah diuraikan mengenai Pengaruh Financial Behaviour, Financial Attitude dan Financial Knowledge Terhadap Financial Literacy di Kota Makassar ( Studi Pada Wanita Berpendidikan Tinggi di Kota Makassar) dapat diperoleh kesimpulan sebagai berikut :

Financial Behaviour yang dimiliki wanita berpendidikan tinggi di Kota Makassar secara keseluruhan berada dalam kategori baik dengan persentase keseluruhan sebesar $73,74 \%$. Hal ini menunjukkan bahwa wanita berpendidikan tinggi di Kota Makassar sudah memiliki financial behaviour yang terlihat baik namun masih perlu ditingkatkan hingga termasuk kategori sangat baik. Dengan financial behaviour yang baik ini, dapat menjadi pedoman untuk mengelola keuangan mereka dengan baik.

Financial attitude yang dimiliki wanita berpendidikan tinggi di Kota Makassar secara keseluruhan berada dalam kategori baik dengan persentase sebesar $82,47 \%$. Hal ini menunjukkan bahwa wanita berpendidikan tinggi di Kota Makassar sudah memiliki financial attitude yang terlihat baik.

Financial Knowledge wanita berpendidikan tinggi secara keseluruhan memiliki ratarata persentase sebesar $84,57 \%$. Angka tersebut masuk dalam kategori sangat baik. Financial Knowledge yang sangat baik ini dapat menjadi pedoman dalam mengelola keuangan secara baik dan tepat.

Financial Literacy wanita berpendidikan tinggi di Kota Makassar memiliki rata-rata persentase sebesar $78,52 \%$ dan termasuk dalam kategori baik. Hal ini menunjukkan bahwa wanita berpendidikan di Kota Makassar sudah memiliki financial literacy yang terlihat baik. Financial literacy yang baik ini dapat menjadi pedoman dalam mengelola keuangan dengan baik dan tepat.

Variabel financial behaviour dan financial attitude secara parsial tidak memiliki pengaruh signifikan terhadap Financial literacy wanita berpendidikan tinggi di Kota Makassar sedangkan variabel financial knowledge secara parsial berpengaruh signifikan terhadap financial literacy wanita berpendidikan tinggi di Kota Makassar.

Berdasarkan hasil Uji F yang dilakukan, variabel Financial Behaviour, Financial Attitude dan financial knowledge secara simultan tidak memiliki pengaruh positif terhadap financial literacy wanita berpendidikan tinggi di Kota Makassar. Hal ini menunjukkan terdapat variabel yang mempengaruhi diluar dari variabel yang diteliti dalam penelitian ini.

\section{DAFTAR PUSTAKA}

Anita, S. (2015). Financial Literacy dan Perilaku Keuangan Mahasiswa. Sekolah Tinggi Ilmu Ekonomi YPPI Rembang, Jawa Tengah

Atkinson, A., Messy P (2012). Measuring financial literacy : Result of the OECD / International Network on Financial Education (INFE) pilot study. OECD working Papers on Finance, Insurance and Private Pensions, No. 15 OECD Publishing. 
Badan Pusat Statistik, (2016). Indikator Kesejahteraan Masyarakat Kota Makassar Tahun 2016, Makassar : Badan Pusat Statistik Kota Makassar.

Bank Indonesia, (2016). Kajian Ekonomi dan Keuangan Regional Provinsi Sulawesi Selatan, Makassar : Bank Indonesia Perwakilan Sulawesi Selatan.

Chaffai, Mustapha. (2014). Behavioral Finance: An Empirical Study of the Tunisian Stock Market. Business School, Sfax University.

Chen, H., \& Volpe, R. P. (1998). An analysis of fi-nancial literacy among collage students. Financial Services Review, 7(1), 107-128.

Fernandes, Daniel. (2013). Financial Literacy, Financial Education and Downstream Financial Behaviors. Erasmus University.

Gina A.N Chowa. (2012). Financial Knowledge and Attitudes of Youth in Ghana.

Ghozali, Imam (2013). Aplikasi Analisis Multivariate dengan Program SPSS. Edisi Ketujuh. Semarang : Badan Penerbit Universitas Diponegoro.

Jatikusumo, H. (2017). Analisis Literasi Keuangan Pada Masyarakat Provinsi DKI Jakarta. Skripsi sarjana pada Universitas Telkom : Tidak Dipublikasikan

Heck, Z. (1984). The Journal of Consumer Education, Vol 2, 1984. Cornel University

Herdjino, I. (2016). Pengaruh Financial Attitude, Financial Knowledge, Parental Income terhadap Financial Management Behavior. Skripsi Sarjana pada Universitas Musamus : Tidak Dipublikasikan

Hemanathan,M. (2011) . Overview of Behavioural Finance. International Journal of Enterprise Innovation Management Studies(IJEIMS) Vol2. No2. ISSN: 0976-2698

Houston, (2010). Measuring Financial Literacy. The Journal of Consumer Affair Vol. 44 No. 2

Indrawati. (2015). Metode Penelitian Manajemen dan Bisnis Konvergensi Teknologi Komunikasi dan Informasi. Bandung : Aditama.

Intansatari, D. (2017). Pengaruh Financial Knowledge, Financial Attitude dan Eksternal Locus Of Control terhadap Personal Financial Management Behavior. Skripsi Sarjana pada Universitas Telkom : Tidak Dipublikasikan.

Jerayam, A.P Sangita. (2016). Financial Literacy and Demographic Factors. Universiti Putra Malaysia Serdang, Selangor Malaysia.

Kiyosaki., T Robert (2008). Increase Your Financial IQ : Get Smarter with Your Money. Boston : Business Plus

Lusardi, A., Mitchell, O. \& Curto, V. (2008). Financial Literacy among the Young.Working Paper of Michigan Retirement Research Center, University of Michigan.

Lusardi, A., Mitchell, O. (2014). The Economic Importance of Financial Literacy: Theory and Evidence. Working Paper of the TIAA-CREF Institute.

Mien dan Thao. (2015). Factors Affecting Personal Financial Management Behaviours: Evidence from vietnam. Proceeding of the Second Asia-Pasific Conference on Global Business, Economics, Finance and Social Sciences (API5Vietnam Conference) ISBN : 978-1-63425-833-6

Nababan, D. (2012). Analisis Personal Financial Literacy dan Financial Behaviour Mahasiswa S-1 Fakultas Ekonomi Universitas Sumatera Utara.

Otoritas Jasa Keuangan, (2016). Survei Nasional Literasi Dan Inklusi Keuangan 2016, Jakarta : Otoritas Jasa Keuangan.

Pankow, Debra (2003). Financial, Values,Attitudes and Goals, North Dakota State University Fargo, North Dakota 58105.

Potrich,C., Viera Mendes,K,. (2015) Determinants of Financial Literacy : Analysis of the Influence of Socioeconomic and Demographic Variables, Universidade Federal de Santa Maria, Centro de Educação Superior Norte-RS, Departamento de Administração, Palmeira das Missões, RS, Brazil.

Chaulagain Ramesh P.(2017). Relationship between Financial Literacy and Behavior of Small Borrowers. Working Paper of NRB.

Ricciardi V.,Simon H. (2000). What is Behavioral Finance?. Business, Education and Technolofy Journal Fall : 2000. 
Remund, D.L. (2010). Financial literacy explicated : The case for a clear definition in an increasingly complex economy. The Journal of Consumer Affairs, 44(2), 276-295.

Robbins, P.S., dan Judge, A.T, (2008). Perilaku Organisasi. Salemba Empat : Jakarta

Sewell, M. (2010). Behavioural Finance, Journal University of Cambridge.

Sinta, C. (2016). Analisis Financial Literacy pada Mahasiswa S-1 Angkatan 2014 Universitas Telkom. Skripsi Sarjana pada Universitas Telkom : Tidak dipublikasikan

Sugiyono. (2010). Metode Penelitian Bisnis (Pendekatan Kuantitatif, Kualitatif Oleh R\&D. Bandung : Alfabeta.

Sunjoyo, dkk. (2013). Aplikasi SPSS Untuk Smart Riset. Bandung : Alfabeta.

Sunyoto, Suyanto (2011). Analisis regresi untuk uji hipotesis. Yogyakarta : Caps.

Virigineni M., Rao M Bhaskara. (2017). Contemporary Developments in Behavioral Finance, International Journal of Economics and Financial Issues, 2017, 7(1), 448459.

Wagner, Jamie. (2015). An Analysis of The Effects of Financial Education on Financial Literacy and Financial Behaviors. Retreived from digitalcommons journal database.

Xiao, J. J., Sorhaindo, B., \& Garman, E. T. 2006. Financial behaviour of consumer in credit counseling. International Journal of Consumer Studies , 101-125.

Zimund dan Babin. (2010). Business Reaserch Methods. South Western : Cengage Learning, 8th edition. 